\title{
In vitro radioautographic studies of the biodistribution of radiopharmaceuticals on blood elements
}

\author{
E. Ripoll-Hamer ${ }^{1,4}$, \\ E.F. De-Paula ${ }^{1}$, L.C. Freitas ${ }^{2}$, \\ M.J.S. Pereira ${ }^{5}$, \\ L.M. Fonseca ${ }^{3,6}$, B. Gutfilen ${ }^{4,6}$, \\ J.J. Carvalho ${ }^{5}$, L.C.M.S. Pôrto 5 \\ and M. Bernardo-Filho ${ }^{1,4}$
}

\author{
${ }^{1}$ Centro de Pesquisa Básica, ${ }^{2}$ Serviço de Quimioterapia and ${ }^{3}$ Serviço de Medicina \\ Nuclear, Instituto Nacional de Câncer, Rio de Janeiro, RJ, Brasil \\ Departamentos de ${ }^{4}$ Biofísica e Biometria and ${ }^{5}$ Histologia e Embriologia, Instituto de \\ Biologia, Universidade do Estado do Rio de Janeiro, Rio de Janeiro, RJ, Brasil \\ ${ }^{6}$ Setor de Medicina Nuclear, Faculdade de Medicina, \\ Universidade Federal do Rio de Janeiro, Rio de Janeiro, RJ, Brasil
}

\section{Correspondence \\ E. Ripoll-Hamer \\ Departamento de Biofísica e \\ Biometria \\ Instituto de Biologia, UERJ \\ Av. 28 de Setembro, 87 \\ 20551-030 Rio de Janeiro, RJ, Brasil \\ Fax: 55 (021) 254-3532}

Presented at the 5th International Symposium on Radioautography, São Paulo, SP, Brasil,

August 24-26, 1997

Research supported by CNPq, INCa and UERJ.

Received September 4, 1997 Accepted November 18, 1997

\begin{abstract}
In the present study we evaluated the binding of the radiopharmaceuticals sodium pertechnetate $\left(\mathrm{Na}{ }^{99} \mathrm{~m} \mathrm{TcO}_{4}\right)$, methylenediphosphonic acid ( $\left.{ }^{99 \mathrm{~m}} \mathrm{Tc}-\mathrm{MDP}\right)$ and glucoheptonate acid ( $\left.{ }^{99 \mathrm{~m}} \mathrm{Tc}-\mathrm{GHA}\right)$ to blood elements using centrifugation and radioautographic techniques. Heparinized blood was incubated with the labelled compounds for $0,1,2$, 3, 4, 6 and 24 h. Plasma (P) and blood cells (BC) were isolated and precipitated with $5 \%$ trichloroacetic acid (TCA), and soluble (SF) and insoluble fractions (IF) were separated. Blood samples were prepared (0 and $24 \mathrm{~h}$ ) and coated with LM-1 radioautographic emulsions and percent radioactivity (\% rad) in $\mathrm{P}$ and $\mathrm{BC}$ was determined. The binding of $\mathrm{Na}{ }^{99} \mathrm{TcO}_{4}(\% \mathrm{rad})$ to $\mathrm{P}$ was $61.2 \%(0 \mathrm{~h})$ and $46.0 \%(24 \mathrm{~h})$, and radioautography showed $63.7 \%(0 \mathrm{~h})$ and $43.3 \%(24 \mathrm{~h})$. The binding to BC was $38.8 \%(0 \mathrm{~h})$ and $54.0 \%(24 \mathrm{~h})$, and radioautography showed $36.3 \%(0 \mathrm{~h})$ and $56.7 \%(24 \mathrm{~h}) .{ }^{99 \mathrm{~m}} \mathrm{Tc}-\mathrm{MDP}$ study presented $91.1 \%(0$ h) to $\mathrm{P}$ and $87.2 \%(24 \mathrm{~h})$, and radioautography showed $67.9 \%(0 \mathrm{~h})$ and $67.4 \%(24 \mathrm{~h})$. The binding to BC was $8.9 \%(0 \mathrm{~h})$ and $12.8 \%(24 \mathrm{~h})$, and radioautography showed $32.1 \%(0 \mathrm{~h})$ and $32.6 \%(24 \mathrm{~h}) .{ }^{99 \mathrm{~m} T c-G H A}$ study was $90.1 \%(0 \mathrm{~h})$ to $\mathrm{P}$ and $79.9 \%(24 \mathrm{~h})$, and radioautography showed $67.2 \%(0 \mathrm{~h})$ and $60.1 \%(24 \mathrm{~h})$. The binding to BC was $9.9 \%$ $(0 \mathrm{~h})$ and $20.1 \%(24 \mathrm{~h})$, and radioautography showed $32.8 \%(0 \mathrm{~h})$ and $39.9 \%$ ( $24 \mathrm{~h}$ ). The comparison of the obtained results suggests that the binding to plasma and blood cells in the two techniques used (radioautography and centrifugation) is qualitatively in accordance.
\end{abstract}

The use of radionuclides is very important for clinical and laboratory evaluations as well as in research. ${ }^{99 \mathrm{~m}} \mathrm{Tc}$ labels a variety of radiopharmaceuticals that are used in nuclear medicine (1-7). There is a growing interest in the biodistribution of radiopharmaceuticals at the cellular and subcellular level. There are two reasons for this: i) the need for knowledge of localization mechanisms, and
Key words

- Radioautography

- Radiopharmaceuticals

- Blood elements ii) the need to consider microdosimetry for both diagnostic and therapeutic radionuclides. Several methods have been developed for the study of microscopic distribution of radiopharmaceuticals. Radioautography has the advantage of permitting simultaneous visualization of tissue and superimposed radioautography is possible. Radioautography studies in which beta particles and secondary 
emissions such as Auger electrons are detected and localized is more commonly used (7-9). When a radiopharmaceutical is administered, part of it binds to blood elements. Differences in percent protein binding may be related to the different pharmacokinetics of each diagnostic agent. The importance of the present study is that it permits the localization of the ${ }^{99 \mathrm{~m}} \mathrm{Tc}$-products in the blood cells and plasma separately. Binding to plasma proteins may influence the radioactivity distribution of each agent $(5,7,10-12)$. It is generally accepted that a variety of factors other than disease can alter the distribution of radiopharmaceuticals and one such factor is drug therapy $(7,13-16)$. We studied the binding of the radiopharmaceutical sodium pertechnetate $\left(\mathrm{Na}{ }^{99} \mathrm{~m} \mathrm{TcO}_{4}\right)$ $(1-7,17,18)$, used for thyroid and brain studies, and compared the results obtained using an in vitro model with reported data obtained with ${ }^{99 \mathrm{~m}} \mathrm{Tc}$-methylenediphosphonic acid $\left({ }^{99 m}\right.$ Tc-MDP) $(7,11,14)$ used for bone studies and ${ }^{99 \mathrm{~m}} \mathrm{Tc}$-glucoheptonate acid $\left({ }^{99 \mathrm{~m}} \mathrm{Tc}-\mathrm{GHA}\right)(7,12,17)$ used for brain and kidney studies.

These experiments were performed without sacrificing the animals. $\mathrm{Na}^{99} \mathrm{mcO}_{4}$ was milked directly from a ${ }^{99} \mathrm{Mo} /{ }^{99 m} \mathrm{Tc}$ generator (Instituto de Pesquisas Energéticas e Nucleares, SP, Brazil) and added to a kit (Laboratório de Radiofarmácia, INCa, Brazil) containing $1 \mathrm{mg} \mathrm{SnCl} .2 \mathrm{H}_{2} \mathrm{O}$ and $10 \mathrm{mg}$ methylenediphosphonic acid to prepare ${ }^{99 \mathrm{~m}} \mathrm{Tc}-\mathrm{MDP}$ and $50 \mathrm{mg}$ of glucoheptonate acid to prepare $99 \mathrm{~m} \mathrm{Tc}-\mathrm{GHA}$. These radiopharmaceuticals were diluted approximately 1000 times with $0.9 \% \mathrm{NaCl}$. Heparinized blood samples $(4.4 \mathrm{ml})$ from Wistar rats were incubated with radiopharmaceuticals. Samples were divided into aliquots of $0.7 \mathrm{ml}$ and incubated for $0,1,2,3,4,6$ and $24 \mathrm{~h}$ with a $50-\mu \mathrm{l}$ solution of the above radiopharmaceuticals. Then, $100 \mu \mathrm{Ci} / \mathrm{ml}(3.7 \mathrm{MBq} / \mathrm{ml})$ was added. Blood smears were prepared, dried and fixed ( 0 and $24 \mathrm{~h}$ ). The preparations were treated with radioautographic emulsions (Amersham, Buckinghamshire, England), developed, fixed, dried and stained. Then, all samples were centrifuged after each time of incubation. Plasma $(\mathrm{P})$ and blood cell (BC) samples $(25 \mu \mathrm{l})$ were isolated and $25 \mu \mathrm{l}$ of $\mathrm{P}$ and $\mathrm{BC}$ were also precipitated with 5\% trichloroacetic acid (TCA) and soluble (SF) and insoluble fractions (IF) were isolated from $\mathrm{P}$ and $\mathrm{BC} . \mathrm{P}$, SF-P, IF-P, SF-BC and IF-BC samples were counted with a well counter and percent radioactivity (\%rad) was calculated in relation to total radioactivity for $\mathrm{P}$ or $\mathrm{BC}$ in $\mathrm{P}+$ $\mathrm{BC}$, for SF or IF of P in SF-P + IF-P, and for SF or IF of BC in SF-BC + IF-BC. The silver grains superimposed on the blood smears were observed under a light microscope (Olympus BH-2) coupled with a computer (IBM-PC). The visualized image was projected onto a video monitor and covered with the $2500-\mu \mathrm{m}^{2}$ image proplus software system grid. The silver grains were then located and counted.

Table 1 shows that in the control the amount of radioactivity in $\mathrm{P}(0 \mathrm{~h})$ was slightly higher than in $\mathrm{BC}$ with $\mathrm{Na}{ }^{99} \mathrm{mcO}_{4}$. There was an increase of $\mathrm{Na}^{99} \mathrm{TcO}_{4}$ binding to $\mathrm{BC}$ within $24 \mathrm{~h}$ both by the centrifugation technique (Table 1) and the radioautographic technique (Table 2). With ${ }^{99 \mathrm{~m} T c-M D P}$ (Table 1) the \% rad in $\mathrm{P}(0$ and $24 \mathrm{~h})$ was higher than in BC. The results obtained with centrifugation (Table 1) and radioautographic (Table 2) techniques showed that the \%rad bound obtained with the two techniques was qualitatively similar. With $99 \mathrm{mTc}-\mathrm{GHA}$ the \% $\mathrm{rad}$ in $\mathrm{P}(0 \mathrm{~h})$ was higher when compared with $\mathrm{BC}$, and decreased with incubation time (24 h) (Tables 1 and 2). The percent of radioactivity binding to $\mathrm{BC}$ was lower at $0 \mathrm{~h}$ and increased within $24 \mathrm{~h}$ (Table 1). Both tested techniques showed that the results were qualitatively similar. This reduced binding to $\mathrm{BC}$ has been reported by several authors $(6,7,12)$. The comparison of radioactivity by both techniques showed that in $\mathrm{BC}$ the activity bound to $\mathrm{Na}{ }^{99} \mathrm{mcO}_{4}$ was higher than the activity 


\begin{tabular}{|c|c|c|c|c|c|c|}
\hline \multicolumn{7}{|c|}{ 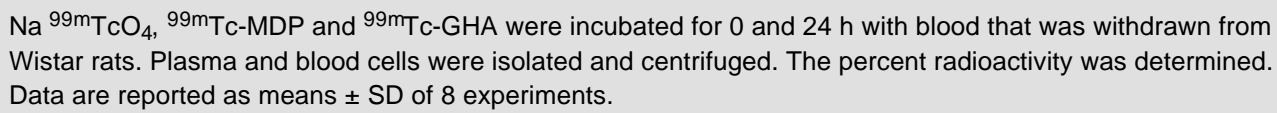 } \\
\hline \multirow[t]{2}{*}{ Time (h) } & \multicolumn{2}{|c|}{$\mathrm{Na}^{99 m \mathrm{mcO}_{4}(\%)}$} & \multicolumn{2}{|c|}{ 99mTc-MDP (\%) } & \multicolumn{2}{|c|}{ 99mTc-GHA (\%) } \\
\hline & Plasma & Blood cells & Plasma & Blood cells & Plasma & Blood cells \\
\hline 0 & $61.2 \pm 2.4$ & $38.8 \pm 2.4$ & $91.1 \pm 1.7$ & $8.9 \pm 1.7$ & $90.1 \pm 2.3$ & $9.9 \pm 2.3$ \\
\hline 24 & $46.0 \pm 0.8$ & $54.0 \pm 0.8$ & $87.2 \pm 1.9$ & $12.8 \pm 1.9$ & $79.9 \pm 2.9$ & $20.1 \pm 2.9$ \\
\hline
\end{tabular}

Table 2 - Radiopharmaceutical distribution between plasma and blood cells determined by a radioautographic technique.

$\mathrm{Na} 99 \mathrm{mTcO}_{4}, 99 \mathrm{mTC}-\mathrm{MDP}$ and $99 \mathrm{mTc}-\mathrm{GHA}$ were incubated for 0 and $24 \mathrm{~h}$ with blood that was withdrawn from Wistar rats. The radioautographic technique was carried out. The silver grains were counted in the blood smears. The percent of radioactivity was determined. Data are reported as means \pm SD of 8 experiments.

\begin{tabular}{|c|c|c|c|c|c|c|}
\hline \multirow[t]{2}{*}{ Time (h) } & \multicolumn{2}{|c|}{$\mathrm{Na}^{99 \mathrm{~m}} \mathrm{TcO}_{4}(\%)$} & \multicolumn{2}{|c|}{ 99mTc-MDP (\%) } & \multicolumn{2}{|c|}{${ }^{99 m} \mathrm{Tc}-\mathrm{GHA}(\%)$} \\
\hline & Plasma & Blood cells & Plasma & Blood cells & Plasma & Blood cells \\
\hline 0 & $63.7 \pm 4.2$ & $36.3 \pm 4.2$ & $67.9 \pm 5.4$ & $32.1 \pm 5.4$ & $67.2 \pm 1.0$ & $32.8 \pm 1.0$ \\
\hline 24 & $43.3 \pm 1.3$ & $56.7 \pm 1.3$ & $67.4 \pm 0.1$ & $32.6 \pm 0.1$ & $60.1 \pm 1.9$ & $39.9 \pm 1.9$ \\
\hline
\end{tabular}

bound to ${ }^{99 \mathrm{~m}} \mathrm{Tc}-\mathrm{MDP}$ and ${ }^{99 \mathrm{~m}} \mathrm{Tc}-\mathrm{GHA}$ (Tables 1 and 2). This probably occurs due to the rapid and strong permeability of $\mathrm{BC}$ to $\mathrm{Na}$ ${ }^{99} \mathrm{mcO}_{4}(19,20)$. Radioautography has been employed by other authors when studying the microscopic distribution of ${ }^{111}$ In-radiopharmaceuticals in normal animal tissues. Linearity of the emulsion response to uniformly labeled tissue is related to the grain density in the radioactivity in the uppermost layers of the section (in immediate contact with the emulsion) (7-9). In comparison, the density of the radioactivity that was counted in BC with $99 \mathrm{~m} \mathrm{Tc}-\mathrm{MDP}$ and $99 \mathrm{~m} \mathrm{Tc}-\mathrm{GHA}$ (Table 2) was higher than that counted by the centrifugation technique (Table 1). The differences in the radioactivity of these radiopharmaceuticals may be explained by the location of the superimposed grain when observed on the plane of the light microscope without three-dimensional visualization (7). Then, some grains that were counted as if they adhered to the cellular membranes belonged, in fact, to P. Despite this limitation, radioautography is an attractive method for studying the biodistribution of radiopharmaceuticals at the microscope level. Computer image analysis is a useful, perhaps indispensable adjunct to this method which permits the processing of large grain numbers and accurately determining grain densities. In conclusion, ${ }^{99 \mathrm{~m}} \mathrm{Tc}$ can be a good alternative radiopharmaceutical for qualitative radioautography studies in substitution of other coumpounds, because it is easily available and normally inexpensive $(2,3,19)$ and permits good resolution. 


\section{References}

1. Bernardo-Filho M (1988). Marcação de estruturas biológicas com ${ }^{99 \mathrm{mT}}$. Doctoral thesis, Universidade Federal do Rio de Janeiro.

2. Bernardo-Filho M, Gutfilen $B$ \& Maciel OS (1994). Technetium-99m binding on plasma proteins and red blood cells: role of various precipitating agents. Biomedical Letters, 50: 17-24.

3. Bernardo-Filho M, Gutfilen B, Souza JEQ, Maciel OS, Boasquevisque EM, Gablay S, Martinho MRJ \& Hasson-Voloch A (1992). Labeling of red blood cells with $99 m_{\text {technetium: a very simple kit. Acta }}$ Medica et Biologica, 33: 811-817.

4. Gutfilen B, Pontes LFS, Alencar ISB \& Bernardo-Filho M (1993). The development of a new and simple technique for labelling mononuclear cells with technetium-99m. Biomedical Letters, 48: 305313.

5. Gutfilen B, Boasquevisque EM \& Bernardo-Filho M (1993). Calcium channel blockers: interference on red blood cells and plasma proteins labeling with 99mTc. Revista Espanhola de Medicina Nuclear, 11: 195-199.

6. Arnold RW, Subramanian G \& McAfee JC (1975). Comparison of ${ }^{99 \mathrm{~m} T c-c o m p l e x e s}$ for renal imaging. Journal of Nuclear Medicine, 16: 357-367.

7. Ripoll-Hamer E (1996). Estudo in vitro do efeito da ciclofosfamida na ligação de radiofármacos aos elementos sanguíneos: comparação com técnica radioautográfica. Master's thesis, Universidade do Estado do Rio de Janeiro.
8. Puncher MRB \& Blower PJ (1995). Frozen sections microautoradiography in the study of radionuclide targeting: application to indium-111-oxine-labelled leukocytes. Journal of Nuclear Medicine, 36: 499-505.

9. Puncher MRB \& Blower PJ (1994). Radionuclide targeting and dosimetry at the microscopic level: the role of microautoradiography. European Journal of Nuclear Medicine, 21: 1347-1365.

10. Vanlic-Razumenic N, Joksimovic J, Ristic B, Tomic M, Beatovc S \& Ajdinovic B (1993). Interaction of ${ }^{99 m}$ Tc-radiopharmaceuticals with transport proteins in human blood. Nuclear Medicine and Biology, 20: 363-365.

11. Vanlic-Razumenic N, Petrovic J \& Gorki D (1982). Binding of Tc-99m-MDP complex by human blood serum constituents. Journal of Labelled Compounds and Radiopharmaceuticals, 19: 1568-1569.

12. Gano L, Patrício L \& Castanheira I (1987). Radiopharmaceuticals for renal studies: evaluation of protein binding. Journal of Radioanalytical and Nuclear Chemistry, 132: $171-178$.

13. Hladik III WB (1993). Drug interactions with radiopharmaceuticals. Fifth European Symposium on Radiopharmacy and Radiopharmaceuticals. Cambridge, England, 32-35.

14. Sampson CB (1993). Adverse reactions and drug interactions with radiopharmaceuticals. Drug Safety, 8: 280-294.
15. Perry CP (Editor) (1991). The Chemotherapeutic Science Book. Williams and Wilkins, Baltimore, Tokyo.

16. Hladik III WB, Nigg KK \& Rhodes BA (1982). Drug-induced changes in the biologic distribution of radiopharmaceuticals. Seminars in Nuclear Medicine, 9: 184218.

17. Eckelman WC, Steigman J \& Paik $\mathrm{CH}$ (1996). Radiopharmaceutical chemistry. In: Harbert JC, Eckelman WC \& Neumann RD (Editors), Nuclear Medicine. Diagnosis and Therapy. Vol. 11. Thieme Medical Publishers, Inc., New York, 213-265.

18. Harbert JC (1996). Production of radionuclides. In: Harbert JC, Eckelman WC \& Neumann RD (Editors), Nuclear Medicine. Diagnosis and Therapy. Vol. 9. Thieme Medical Publishers, Inc., New York, 195211.

19. Hladik III WB, Saha GB \& Study KT (Editors) (1987). Essentials of Nuclear Medicine Science. Williams and Wilkins, Sydney.

20. Burdine JA \& Legeay R (1968). Spleen scans with Tc-99m-labeled heated erythrocytes. Radiology, 91: 162-164. 